УДК 536.24:662.92

\title{
COMPREHENSIVE ANALYSIS OF TRANSFER PROCESSES IN MODERN HIGH-TEMPERATURE HEAT EXCHANGERS
}

\author{
Soroka B., Zgurskyi V. \\ Gas Institute of NASU, Kiev 03113, Ukraine
}

https:doi.org/10.31472/ttpe.3.2019.4

Проведено CFD моделювання високотемпературного трубчастого теплообмінника. Розглянуті результати чисельного аналізу впливу вторинних випромінювачів (SEE) усередині труб та між трубами на інтенсивність та рівномірність результуючого теплообміну. Внутрішні SEE мають визначальний вплив на теплопередачу, збільшуючи результуючий тепловий потік до 40\%.
Проведено CFD моделирование высокотемпературного трубчатого теплообменника. Рассмотрены результаты численного анализа влияния вторичных излучателей (SEE) внутри труб и между трубами на интенсивность и равномерность результирующего теплообмена. Внутренние SEE имеют определяющее влияние на теплопередачу, увеличивая результирующий тепловой поток до $40 \%$.
The CFD modeling of hightemperature tube heat exchanger has been carried out. The results of numerical analysis of internal and external secondary emitters' (SEE) influence upon intensity and uniformity of resulting heat transfer have been presented and discussed. An internal SEE have the determining impact upon heat exchange process thus enhancing the resulting heat flux till extra $40 \%$.

References 4, tables 1, figures 5.

Key words: energy saving, high temperature heat exchanger, recuperator, Reynolds analogy, secondary emitters.

$\dot{m}$ - mass flow, $\mathrm{kg} / \mathrm{s}$;

$t$ - temperature, ${ }^{\circ} \mathrm{C}$;

$T$ - temperature, $\mathrm{K}$;

$\bar{\alpha}-$ heat transfer coefficient, $\mathrm{W} /\left(\mathrm{m}^{2} \cdot \mathrm{K}\right)$;

$\Delta p$ - pressure drops, $\mathrm{Pa}$.

\section{Subscripts:}

$a-$ air;

$C P-$ combustion products.

\section{Introduction}

Using of the turbulizing inserts inside the tube channels represents the world practice of heat transfer enhancement in low-and middle - temperature heat exchangers [1-3]. The same approach is traditionally used by designing and manufacturing the high-temperature recuperators - heat recovery units.

The spiral inserts in form of the twisted tapes TT, sometimes with additional turbulizing elements, make one of the most wide-spread facilities of indicated purpose, applied mainly for enhancing the heat transfer in the system "heating flow - heat transfer surface".

In the Gas Institute have been proposed the secondary emitters SE of new design the internal inserts distinctive by enhanced efficiency and reduced hydraulic resistance along with the external SE [4]. Below are considered the calculation results of testing the heat exchanger with new designs of SE.

1. The CFD modeling approaches have been developed to analyze the possibilities of enhancement (intensifying) and equalization the resulting heat fluxes by heat absorption

\author{
Abbreviations: \\ $\mathrm{BD}$ - basic design; \\ HE - heat exchanger; \\ SEE - secondary emitters.
}

surfaces due arrangement the internal and external inserts in frame of modernization the tubular convective heat exchangers.

Mentioned advancing means have been studied by evaluation of four versions of the heat exchanger designs and of arrangement the proper SEE (Fig. 1): 1). basic version (without SEE); 2). basic design + external SEE; 3). basic design + internal SEE; 4). basic design + internal SEE + external SEE.

The numerical simulation procedures with fluid dynamics and heat transfer studies: on resulting local heat fluxes, temperature non-uniformity and total heat reception were performed under boundary conditions of the third kind.

All the predicted temperature characteristics of recuperative section under consideration have been studied, analyzed and generalized within the temperature range for hot heat transfer medium $t_{C P} \in\left\{500 ; 1000^{\circ} \mathrm{C}\right\}$. The simplified design of the tube heat exchanger conditionally consisting of 4 (four) longitudinal rows of vertical tubes and of 3 (three) transversal rows is presented in Fig.1. Height of tubes makes $1 \mathrm{~m}$; outer diameter each of them is equal $73 \mathrm{~mm}$. 
In the upper part of the Fig. 1 is shown the sketch of the basic design of the heat exchanger section of plain (hollow) tubes without any SEE.

An air flow to be preheated is moving through the vertical tubes supplied with in - tube cruciform inserts in versions 3 and 4 (Fig.1). The tubes are joined at the ends: above - by upper cold air collector, below the tubes - by the lower (hot air) collector.

The hot heat transfer medium is presented by combustion products flow moving along and between the longitudinal tube rows.

It has been stated in respect to involvement the internal and external secondary emitters by designing the middle and high - temperature furnace recuperators that possibility of enhancement the resulting heat fluxes (heat reception) is growing by the following sequence of the versions and enhancement approaches: beginning from the $1^{\text {st }}$ and finishing the $4^{\text {th }}$ above mentioned version (Fig.1).
In Fig.2 are presented the patterns of the flows moving within and between the tubes by means of visualization the temperature (Fig.2,a) and velocity (Fig.2,b) profiles. Presented information is related to longitudinal horizontal plane at mid-height of the vertical tubes of heat exchanger.

The resulting temperature patterns are non-uniform within the primary and secondary flows and on the walls surface of the tubes by their length (height) and at the exit of heat exchanger.

The temperatures are changed from tube to tube, by each tube length (height) and around the tube. By this reason the final temperature profiles are considered and compared by means of option the most preferable characteristic indicators - the tube walls temperatures of maximum and of averaged values.

2. In Fig. 3 the correlation of the resulting heat recovery flux of the recuperative heat exchanger is presented in form of an increment of the coolant preheat - an air flow

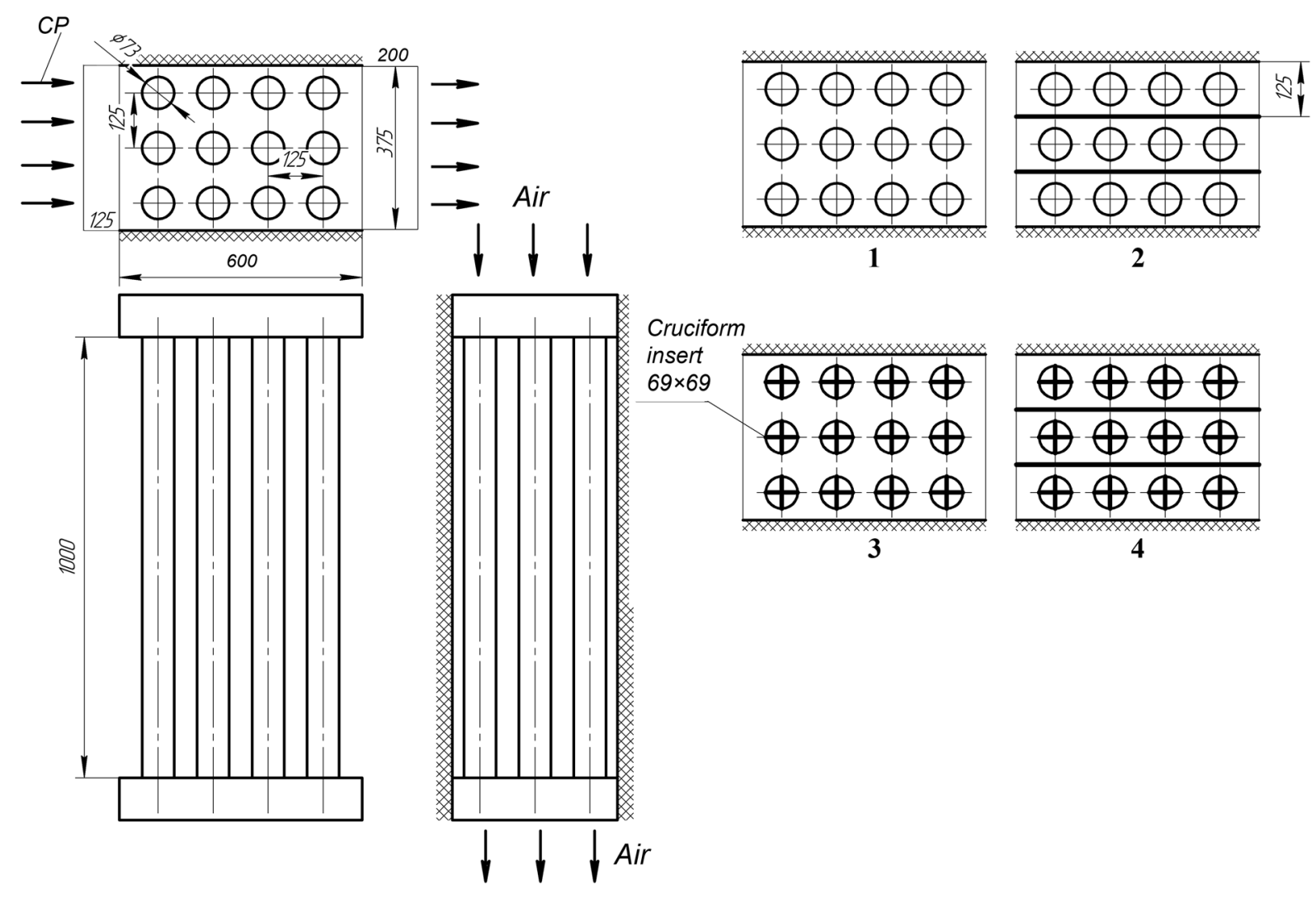

Figure 1. The computation schemes of recuperative heat exchange section with enter (upper) and outlet (lower) collectors. Cross - section horizontal view for the next designs of recuperative section. 1 - no inner or external SEE, plain tubes without the inserts $S E E$ (basic version); 2 - external SEE plate inserts between the longitudinal tube rows; 3 - inner SEE (of crossing plate insert); 4 - combined system of SEE: inner - within the tubes - and external - between the longitudinal tube rows. 
temperature gain $\Delta t_{a}$ - depending on the combustion products temperature $t_{C P}\left(T_{C P}\right)$ at the entrance to the heat exchanger. Installation of the secondary emitters: internal ones - inside the tubes - and external ones - between and parallel to the longitudinal rows of the tubes (Fig. 1) - provides significant increase the heat exchanger's efficiency. An enhancement of the heat exchanger's thermal (energy) efficiency by course of rise the $t_{C P}\left(T_{C P}\right)$ is observed due to the concomitant
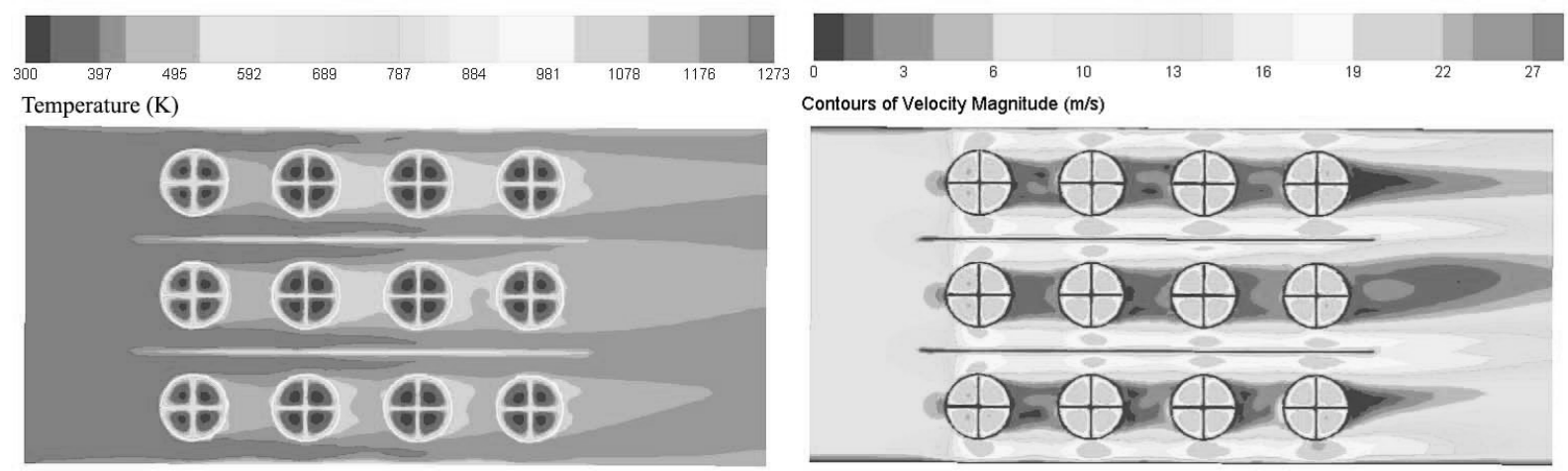

Figure 2. Temperature (a) and velocity (b) profiles of flue gases flow channels within longitudinal horizontal cross section at the middle by height of the recuperative section. Mass flows, $\mathrm{kg} / \mathrm{s}$ : an air $-\dot{m}_{a}=0.772$; combustion products $\dot{m}_{C P}=0.84$.

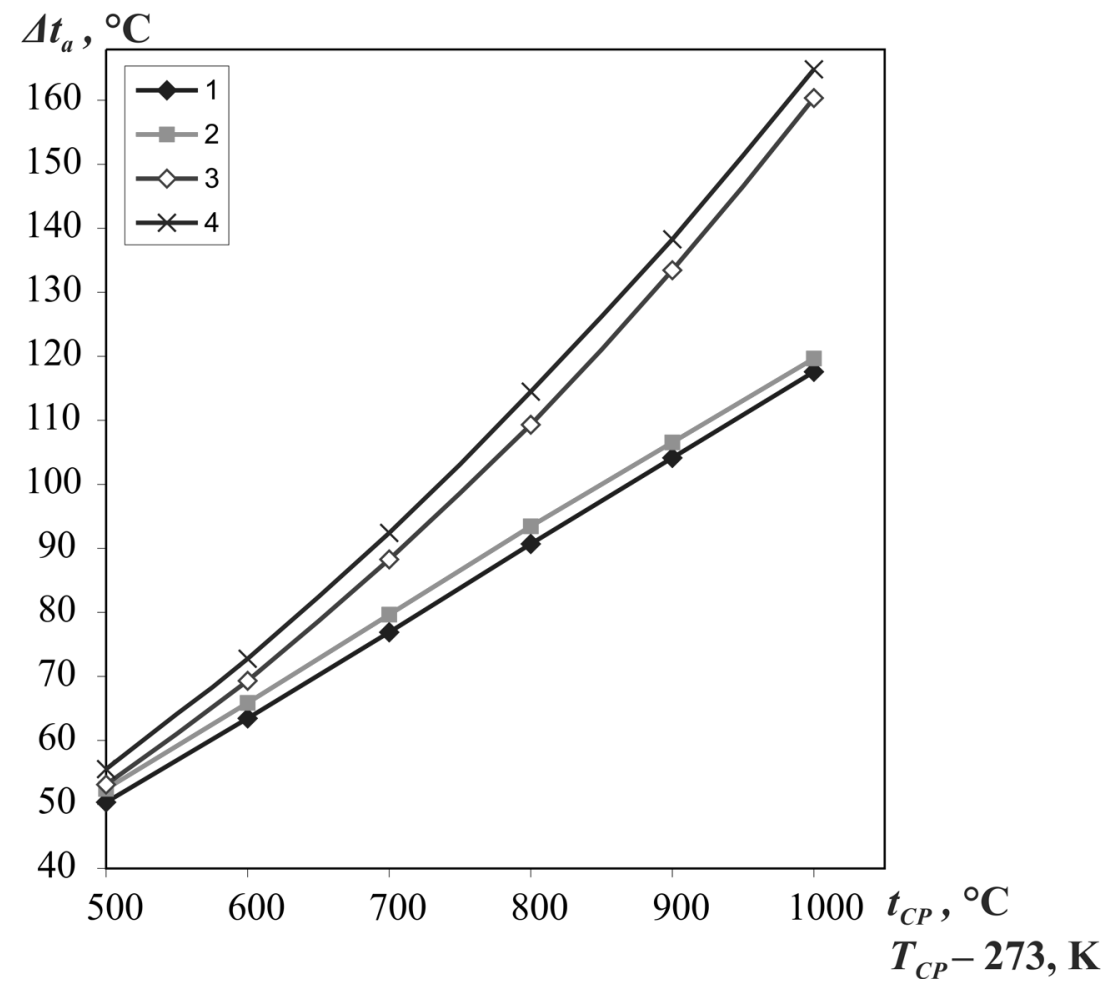

Figure 3. Dependence of an air preheating, ${ }^{\circ} \mathrm{C}$, by the length of recuperative section on flue gases (combustion products) temperature. An air temperature at the entrance into recuperator $T_{a, e n}=300 \mathrm{~K}\left(27^{\circ} \mathrm{C}\right)$. Mass flows, $\mathrm{kg} / \mathrm{s}$ : an air $-\dot{m}_{a}=0.772$; combustion products $\dot{m}_{C P}=0.84$. Arrangement of the secondary emitters SEE: 1 - without the inserts (plain, hollow channels) BD; 2 - the plates within the intertube space ESE; 3 - inserts within the tubes ISE; 4 - inserts within the tubes and the plates within the intertube space (BD+ISE+ESE). 
increase the contribution of the indirect radiation component of heat exchange process. This contribution to the net heat flux transferred to the air coolant is provided by the surface of the longitudinal external inserts.

However, with increasing the temperature $T_{C P}$ by rise the corresponding external heat fluxes values, growth of limiting impact of the inner component of heat exchange process within the system "combustion products - tube channel walls - an air flow" is enhancing. This statement could be explained by lower value of inner heat transfer component (namely - the convective heat transfer within the tubes) comparatively to the external constituent. Such correlation is stipulated by the basic radiative transparency of the coolant (an air flow within the tubes).

By this reason, the remarkable role of the inner inserts (particularly - of cruciform shape) is observed (Fig.3) being significantly superior to contribution of outward (external) secondary emitters. Nevertheless the installation of longitudinal intertube plane partitions being located to the tube heat receiving surfaces and parallel to the longitudinal tube rows improves the heat exchanger efficiency and thermal stability due smoothing the heat fluxes by receiving surfaces.

The relative heat transfer enhancement compared to 1 -st scheme (using of BD), \%, for tested schemes (circuits) of heat exchanger (Fig. 1) is illustrated by the Table 1.

Table 1. Heat transfer enhancement compared to BD, \%, depending on the heat exchanger scheme (circuit)

\begin{tabular}{|c|c|c|c|}
\hline $\boldsymbol{T}_{\mathrm{CP}},{ }^{\circ} \mathbf{C}$ & $\begin{array}{c}\mathbf{3} \\
\text { BD+ESE }\end{array}$ & $\begin{array}{c}\mathbf{3} \\
\text { BD+ISE }\end{array}$ & $\begin{array}{c}\mathbf{4} \\
\text { BD+ISE+ESE }\end{array}$ \\
\hline 600 & $4-5$ & 10 & 15 \\
\hline 1000 & $2-3$ & 36 & 40 \\
\hline
\end{tabular}

By arrangement the inner inserts the limiting role of in - tube heat transfer is diminished and an opportunity to increase the resulting heat flux transferred from the combustion products $\mathrm{CP}$ to an air flow within the tube is risen (Fig.3).

In this connection the case of supplying the tube channels with the inserts is more flexible to absorb the increased heat fluxes by growth the values of $T_{C P}$ than for the cases of ordinary hollow tube channels or when arrangement the outer SEE between the longitudinal tube rows is envisaged (see Fig.3). Really by comparing the impact of different ways of enhancement an air preheat due using the SEE: inner and external - it could be seen that the in - tube inserts provide much greater relative rate of heat transfer than external plates.
3. The problem of an exclusive importance the temperature patterns of the tube surfaces by operation the high temperature heat exchangers (HE) has a great importance because the temperature state defines the service life of the HE.

Simultaneously with better heat absorption by air flow for the cases of using the inner SEE within the tube channels of recuperative section, the temperature state of the tube walls is changed and improved. It means lowering the temperature of the tube walls and reducing the temperature difference between the tube walls and the working body (an air flow).

4. The hydraulic resistance (pressure losses) by length of tube channels for four different versions of HE (Fig.1) are mainly determined by presence or absence of the in - tube inserts within an air channels, on the one hand, and on flue gases temperature $t_{C P}$ ahead of HE, on the other hand Fig. 4 . The diagram of dependence the pressure drop by an air flow channels of the heat exchanger HE under consideration is presented in Fig.4 in frame of further from the standpoint of Reynolds analogy (Fig.5).

As could be seen from Fig. 4 the simple using of external SEE practically doesn't affect on dependence $\Delta p_{a}\left(t_{C P}\right)$ while an arrangement the in-tube inserts (internal SEE) alters the proper curve significantly. This situation is explained by great increase of the tube channel(s) hydraulic resistance in case of installation the inserts both by the reasons of partial block the channel's cross-section, change the flow trajectory within the channel, on the one hand, and on increase of an air flow preheat due enhancement of heat transfer, on the other hand.

It has been stated as the results of theoretical investigation carried out by means of CFD modeling that the Reynolds analogy in the tube recuperative heat exchanger doesn't observe generally as occurrence. By this in the temperature range for combustion products before $\mathrm{HE} t_{C P} \leq 600^{\circ} \mathrm{C}$ an opportunity non-observance the similarity of heat transfer and the hydraulic resistance of the channels could be ignored: divergence exceed 3\%. Mentioned situation is stipulated by mainly convective transfer of energy (heat) and momentum by indicated temperature range of hot heat transfer medium. Really, the same conclusion follows by analysis of dependence the summary (conditional, of reduced value) heat transfer coefficient $\bar{\alpha}_{r s}$ on the side of inner surface for HE tubes under comparison the different designs of HE: the basic HE section design BD of the plain tubes without the inserts; the designs with spiral inserts SP1, SP2. Mutual arrangement of curves 1, 2, 3, 4 by comparison of different temperature and pressure losses characteristics is insignificantly influenced by $t_{C P}$ value. 


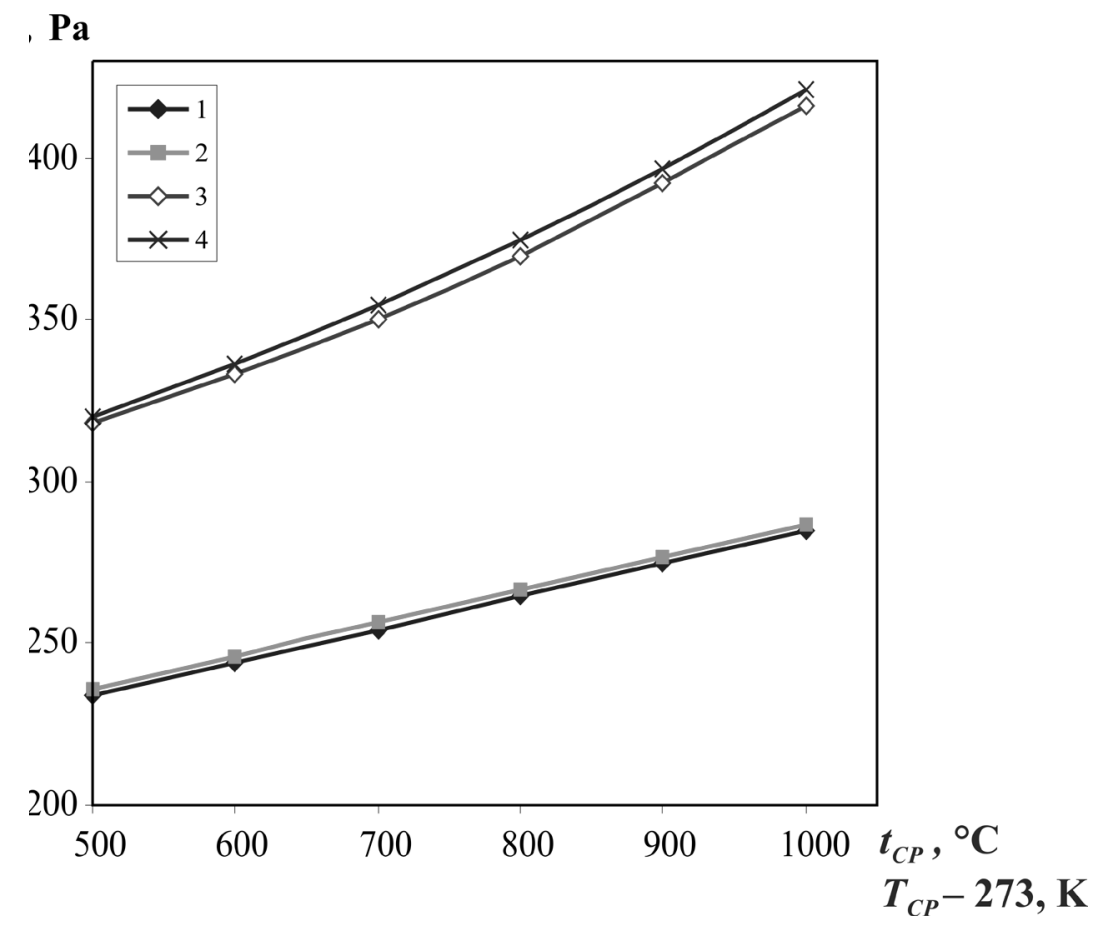

Figure 4. Dependence of hydraulic resistance (pressure losses by the length of an air pathway of the recuperative section) on combustion products (flue gases) temperature $t_{C P}$ in front of heat exchanger.

The nomenclature and computing conditions - see Figure 3.

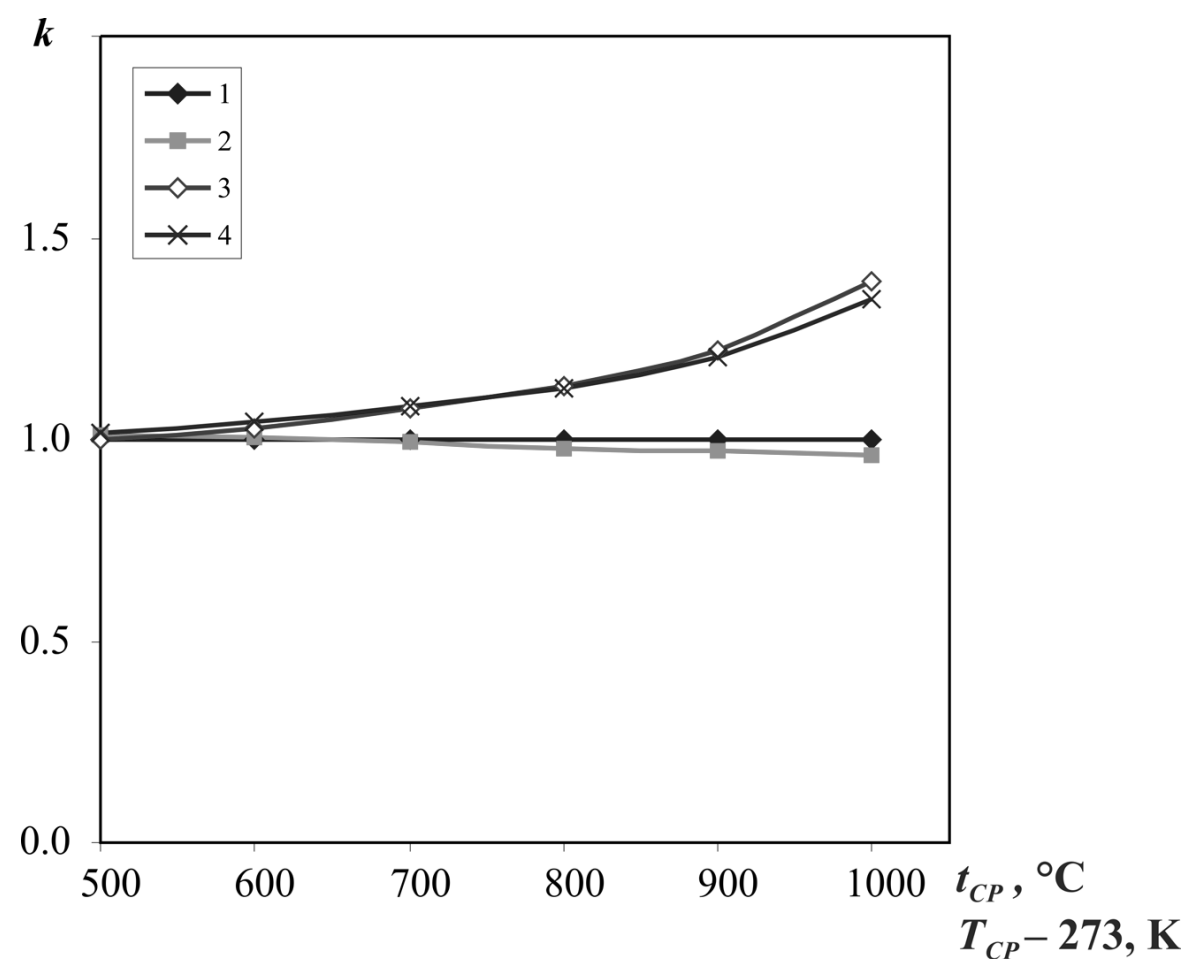

Figure 5. Dependence of Reynolds analogy factor compared with the basic design $k$ for heat exchange and hydraulic resistance by operation the recuperative section, on combustion products (flue gases) temperature $t_{C P}$. The nomenclature and computing conditions-see Figure 3. 


\section{Conclusion}

The dominating impact of arrangement the internal inserts serving as secondary emitters inside the tube heat exchange surface (schemas 2 and 4) comparing with the basic design of heat exchanger BD (scheme 1) has been proved. The advantages of designs with the secondary emitters are growing by increase of combustion products' temperature tCP due involvement the radiative component of heat exchange into resulting heat flux.

The proposed approach ensures an optimization the design of the heat exchanger from the standpoint of combined thermal and hydraulic characteristic and gives an opportunity to make selection of the materials for manufacturing the high-temperature recuperative heat exchangers.

\section{REFERENCES}

1. Man C., Lv X., Hu J., Sun P., and Tang Y., Experimental study on effect of heat transfer enhancement for single-phase forced convective flow with twisted tape inserts, International Journal of Heat and Mass Transfer, 2017, Vol.106, pp.877-883.

2. Man Z. C., Yao J. and Wang C., The Experimental study on the Heat Transfer and Friction Factor Characteristics in tube with a new kind of twisted tape insert, Int. Commun. Heat Mass Transf., 2016,Vol.75, pp. 124-129.

3. Maximize Thermal Efficiency. Minimize Footprint. Media Library Funding Incentives, Fuel Efficiency LLC. Clyde, New York., 2018, pp.1-6.

4. Soroka B., Vorobyov M., Zgurskyi V. et al., Heat transfer and Aerodynamic Resistance of Modern HighTemperature Tube Heat Exchanger Equipped with the inTube Inserts, Proceedings of XV Minsk Intern. Heat and Mass Transfer Forum. Scientific Edition, Minsk. 23 - 26 May, 2016, Vol.3, pp.206-210. 


\section{КОМПЛЕКСНИЙ АНАЛІЗ ПРОЦЕСІВ ПЕРЕНОСУ В СУЧАСНИХ ВИСОКОТЕМПЕРАТУРНИХ ТЕПЛООБМІННИКАХ}

Сорока Б.С., д.т.н., Згурский В.О., к.т.н.

Інститут газу НАН Украӥни, вул. Дегтярівська 39, м. Київ, 03113, Україна

https:doi.org/10.31472/ttpe.3.2019.4

Мета. Визначення можливостей інтенсифікації теплообміну при нагріві прозорого для випромінювання теплоносія в конвективних трубчастих теплообмінниках шляхом встановлення внутрішніх та зовнішніх вторинних випромінювачів для додаткового забезпечення радіаційної складової теплообміну всередині труб.

Методика. В роботі використано метод CFD моделювання теплообмінника 3 двома трубними дошками, між якими розташовані ряди вертикальних труб вздовж та поперек течії гарячого теплоносія - продуктів згоряння.

Результати. Розглянуто 4 схеми розміщення теплообмінних труб: базова конструкція без вставок (BD), базова конструкція із внутрішніми вставками, BD iз зовнішніми вставками, BD із внутрішніми i зовнішніми вставками. Визначено розподіл температур теплообмінних поверхонь труб, картина течій, теплові потоки та гідравлічні втрати в рекуперативній секції.

Визначені температурні розподіли нагріву повітря та поверхонь труб, які статистично оброблені з отриманням усереднених по поверхням, а також максимальних локальних значень температур. Встановлена кардинальна зміна швидкості нагріву повітря в трубах і зниження температури стінок при установці внутрішніх вставок в трубах.

Наукова новизна. Встановлено, що традиційні трубчасті теплообмінники, призначені для нагріву прозорого для випромінювання середовища (повітря), тим значніше обмежують можливість передачі теплоти від гарячого теплоносія (продуктів згоряння), що рухається в міжтрубному просторі, чим вище температура продуктів згоряння. Зазначені обмеження успішно долаються завдяки розміщенню вторинних випромінювачів всередині труб.
Визначено межі існування аналогії Рейнольдса щодо перенесення теплоти і імпульсу. При температурі потоку продуктів згоряння до $600{ }^{\circ} \mathrm{C}$ можна вважати аналогію Рейнольдса існуючою, а фактор аналогії - близьким до 1,0 , тобто стверджувати подібність інтенсивності конвективного теплообміну (чисел $\mathrm{Nu}$ ) і гідравлічного опору повітряного тракту (Cf).

Практична значимість. Проведені дослідження забезпечують нові підходи до проектування високотемпературних теплообмінників, ефективність яких пов'язана з використанням внутрішньотрубних вторинних випромінювачів. Сучасні рекуперативні теплообмінники мають бути по всій довжині оснащені вставками, що мають переважно форму сполучення радіальних ребер.

Ключові слова: аналогія Рейнольдса, високотемпературний теплообмінник, вторинні випромінювачі, енергозбереження, рекуператор

Бібл. 4, рис. 5, табл. 1.

1. Man C., Lv X., Hu J., Sun P., and Tang Y., Experimental study on effect of heat transfer enhancement for single-phase forced convective flow with twisted tape inserts, International Journal of Heat and Mass Transfer, 2017, Vol.106, pp.877-883.

2. Man Z. C., Yao J. and Wang C., The Experimental study on the Heat Transfer and Friction Factor Characteristics in tube with a new kind of twisted tape insert, Int. Commun. Heat Mass Transf., 2016,Vol.75, pp. 124 - 129.

3. Maximize Thermal Efficiency. Minimize Footprint. Media Library Funding Incentives, Fuel Efficiency LLC. Clyde, New York., 2018, pp.1-6.

4. Soroka B., Vorobyov M., Zgurskyi V. et al., Heat transfer and Aerodynamic Resistance of Modern HighTemperature Tube Heat Exchanger Equipped with the inTube Inserts, Proceedings of XV Minsk Intern. Heat and Mass Transfer Forum. Scientific Edition, Minsk. 23 - 26 May, 2016, Vol.3, pp.206-210.

Отримано 30.05.2019 Received 30.05.2019 